\title{
ORIGINAL ARTICLE Evolution of nickel hyperaccumulation and serpentine adaptation in the Alyssum serpyllifolium species complex
}

\begin{abstract}
MK Sobczyk ${ }^{1}$, JAC Smith ${ }^{1}$, AJ Pollard ${ }^{2}$ and DA Filatov ${ }^{1}$
Metal hyperaccumulation is an uncommon but highly distinctive adaptation found in certain plants that can grow on metalliferous soils. Here we review what is known about evolution of metal hyperaccumulation in plants and describe a population-genetic analysis of the Alyssum serpyllifolium (Brassicaceae) species complex that includes populations of nickelhyperaccumulating as well as non-accumulating plants growing on serpentine (S) and non-serpentine (NS) soils, respectively. To test whether the $S$ and NS populations belong to the same or separate closely related species, we analysed genetic variation within and between four S and four NS populations from across the Iberian peninsula. Based on microsatellites, genetic variation was similar in $S$ and NS populations (average $H_{0}=0.48$ ). The populations were significantly differentiated from each other (overall $F_{\mathrm{ST}}=0.23$ ), and the degree of differentiation between $\mathrm{S}$ and NS populations was similar to that within these two groups. However, high S versus NS differentiation was observed in DNA polymorphism of two genes putatively involved in adaptation to serpentine environments, IREG1 and NRAMP4, whereas no such differentiation was found in a gene (ASIL1) not expected to play a specific role in ecological adaptation in $A$. serpyllifolium. These results indicate that $\mathrm{S}$ and NS populations belong to the same species and that nickel hyperaccumulation in $A$. serpyllifolium appears to represent a case of adaptation to growth on serpentine soils. Further functional and evolutionary genetic work in this system has the potential to significantly advance our understanding of the evolution of metal hyperaccumulation in plants.
\end{abstract}

Heredity (2017) 118, 31-41; doi:10.1038/hdy.2016.93; published online 26 October 2016

\section{INTRODUCTION}

Metal hyperaccumulation in plants

One of the most extraordinary adaptations known in the plant kingdom is the ability of certain plants to hyperaccumulate trace elements in their above-ground biomass. This trait is present in only $\sim 500$ species, representing $<0.2 \%$ of all angiosperm species (Reeves and Baker, 2000; Verbruggen et al., 2009; Krämer, 2010; Van der Ent et al., 2013). In contrast to metal excluders whose strategy is to control the uptake of metals into the root and prevent metal translocation to aerial organs, hyperaccumulators accumulate metals in the shoot to levels toxic to most other plants (Baker, 1981; Baker and Brooks, 1989; Baker et al., 2000; Pollard et al., 2002; Krämer, 2010; Rascio and Navari-Izzo, 2011). This is remarkable as the photosynthetic apparatus is one of the major targets of metal phytotoxicity, typically resulting in severe symptoms such as chlorosis and necrosis, wilting, abnormal development and reduced growth (Pandey and Sharma, 2002; Rahman et al., 2005; Marschner and Marschner, 2012). These toxic effects are a product of numerous harmful interactions at the cellular level (Haydon and Cobbett, 2007), including nonspecific binding of metals to enzyme functional groups and displacement of other metals from their binding sites, generation of reactive oxygen species by redox-active metals that can lead to disruption of the electrontransport chain (Qadir et al., 2004), lipid peroxidation and subsequent impairment of membrane integrity (Pandolfini et al., 1992; Ros et al., 1992; Gonnelli et al., 2001; Haydon and Cobbett, 2007; Krämer, 2010; Hanikenne and Nouet, 2011).
Of various hypotheses proposed to explain the possible adaptive advantage conferred by hyperaccumulation of metals (Boyd and Martens, 1992), only the herbivore/pathogen 'elemental defence' hypothesis has gathered plentiful supporting experimental evidence (Boyd, 2004, 2007). There have been many reports of decreased herbivory or reduced pathogen infection on plants hyperaccumulating metals (Poschenrieder et al., 2006; Boyd, 2007; Fones et al., 2010; Rascio and Navari-Izzo, 2011). However, in some studies no protective effect of metal hyperaccumulation against herbivory was observed (Noret et al., 2007), and designing trials to demonstrate such an effect in the field is particularly challenging, and hence further work is required to substantiate the selective advantage offered by metal hyperaccumulation. Nonetheless, it remains broadly true that hyperaccumulator species show a very high degree of metal tolerance (otherwise the accumulation of such exceptional concentrations of metals in the shoot would be suicidal), and that the degree of metal tolerance of different species or populations tends to be quite closely correlated with the metal content of the natural substrates on which they grow (Antonovics et al., 1971; Roosens et al., 2003; de la Fuente et al., 2007; Pollard et al., 2014).

Two broad hypotheses have been considered in the literature regarding the origin and spread of metallicolous populations, that is, those adapted to soils containing an elevated concentration of a particular metal (Pauwels et al., 2005). One is based on the observation that populations inhabiting metalliferous outcrops are often separated by large geographic distances; this would limit dispersal and genetic

${ }^{1}$ Department of Plant Sciences, University of Oxford, Oxford, UK and ${ }^{2}$ Department of Biology, Furman University, Greenville, SC, USA Correspondence: DA Filatov, Department of Plant Sciences, University of Oxford, South Parks Road, Oxford OX1 3RB, UK.

E-mail: Dmitry.Filatov@plants.ox.ac.uk

Received 27 February 2016; revised 7 August 2016; accepted 12 August 2016; published online 26 October 2016 
exchange between metallicolous populations, and instead would favour evolution of locally adapted metallicolous populations from nearby non-metalliferous sites (Schat et al., 1996) driven by ecological speciation (Rundle and Nosil, 2005). The other hypothesis proposes a single origin of a genetic adaptation to metalliferous substrates, its spread across outlying metalliferous sites and subsequent differentiation between more recently established metallicolous populations because of genetic drift. These alternative views resonate with earlier debates as to whether local populations of metal-tolerant plants occurring on metalliferous outcrops represent 'neoendemics' or 'palaeoendemics', respectively (equivalent to the 'insular' and 'depleted' species of Stebbins (1942), as discussed by Kazakou et al. (2008)). Correspondingly, non-metallicolous populations of such species could be either ancestral, as in the first scenario, or locally derived from metallicolous populations, as in the second.

\section{Evolution of metal tolerance in plants}

The question of whether metal tolerance is a constitutive trait across all populations of a species, or the degree to which ecotypic differentiation has occurred in response to different substrates, has been one of the most important issues underpinning hypotheses concerning the evolutionary origins of this trait. Two of the most intensively studied species of hyperaccumulator plants, Arabidopsis halleri (L.) O'Kane \& Al-Shehbaz (formerly Cardaminopsis halleri (L.) Hayek) and Noccaea caerulescens (J Presl and C Presl) FK Mey. (formerly Thlaspi caerulescens J Presl and C Presl), display a basal, constitutive level of zinc tolerance and hyperaccumulation in both metallicolous and non-metallicolous populations (Meerts and Van Isacker, 1997; Bert et al., 2000, 2002; Escarré et al., 2000; Frérot et al., 2003; Pauwels et al., 2006; Meyer et al., 2010). However, across the geographic range of these species, there is a significant positive correlation between the degree of tolerance and substrate metal concentration, indicative of local adaptation to the natural habitat (Roosens et al., 2003; Pauwels et al., 2005). The relationship between metal tolerance and hyperaccumulation is rather less clear, and although the highest shoot metal concentrations observed in the field are found in populations growing on metalliferous soils, there is some evidence that the level of metal hyperaccumulation shown by these populations may be inversely related to their degree of metal tolerance (Bert et al., 2000; Roosens et al., 2003).

Although it is generally believed that the emergence of the hyperaccumulation trait in these two model species was driven by, and coincident with, the appearance of anthropogenic metal-polluted sites in the mining regions of Europe (Pauwels et al., 2006; JiménezAmbriz et al., 2007; Besnard et al., 2009), recent research on A. halleri supports a much more ancient appearance of the trait-or at least selection on major genes responsible for the trait-during the speciation process giving rise to this lineage hundreds of thousands of years ago, and thus pre-dating any human industrial activity (Roux et al., 2011). It has been suggested that major loci involved in metal tolerance and accumulation, such as the HMA4 gene (encoding the plasma membrane ATPase responsible for transporting $\mathrm{Zn}^{2+}$ out of root cells for loading into the xylem and translocation to the shoot), were targets of selection early in the history of the species (Pauwels et al., 2005; Roux et al., 2011). This would have established a basal level of zinc tolerance and accumulation in A. halleri, with local selection subsequently acting on additional genes in each established metallophyte population to enhance metal tolerance and possibly hyperaccumulation capacity still further (cf. Macnair, 2003). This has been supported by the results of genome-scan analyses that have shown the presence of outliers specific to different metallicolous populations of A. halleri (Meyer et al., 2009). Large variation in the degree of zinc tolerance within non-metallicolous populations and individuals can then be explained by either local gene flow from metallicolous to non-metallicolous populations, or as a result of ancestral standing genetic variation present within the nonmetallicolous populations, that may have been exploited as the initial basis for metal tolerance in metallicolous populations.

\section{Nickel hyperaccumulation}

Metal hyperaccumulator plants are known to accumulate zinc, cadmium, copper, cobalt, manganese and the metalloids arsenic, thallium and selenium, but the largest number ( $80 \%)$ of hyperaccumulator species described are known to accumulate nickel (Reeves and Baker, 2000; Verbruggen et al., 2009; Krämer, 2010), possibly because of its prevalence in ultramafic rocks across the continents (Van der Ent et al., 2013). Ultramafic substrates are derived from igneous rocks with a low silica content but rich in mafic minerals such as magnesium, iron and nickel. Weathering of ultramafic bedrock creates serpentine soils with distinctive physical and chemical characteristics, including particularly high contents of nickel, cobalt and chromium, high $\mathrm{Mg} / \mathrm{Ca}$ ratio and low levels of the essential macronutrients nitrogen, phosphorus and potassium (Brooks, 1987; Kazakou et al., 2008). Most types of soil show nickel concentrations typically between 7 and $50 \mathrm{mg} \mathrm{kg}^{-1}$, whereas in serpentine soils the nickel content usually ranges from 700 to $8000 \mathrm{mg} \mathrm{kg}^{-1}$ (Reeves, 1992; Reeves and Baker, 2000). This characteristic geochemistry, combined with a characteristically thin soil cover and granular texture, poor water-holding capacity, ready erosion and exposure to high light intensity, makes serpentine soils a notoriously difficult environment for plant growth (Proctor, 1975; Freitas et al., 2004). As a result, serpentine outcrops are treated as ecological islands inhabited by specialised floras. Indeed, the discontinuity between serpentine outcrops, with their sparse vegetation, and neighbouring soils can often be clearly delimited from afar (Kruckeberg, 2004; Brady et al., 2005).

Despite the greater taxonomic abundance of nickel hyperaccumulator species $(>400)$, much more research has so far been conducted on the molecular basis and evolution of zinc and cadmium hyperaccumulation in the de facto model organisms A. halleri and $N$. caerulescens. However, only 15 described species are known to display zinc hyperaccumulation (Meerts and Van Isacker, 1997; Bert et al., 2000; Krämer, 2010), and nickel hyperaccumulation warrants further research as part of attempts to understand the evolutionary basis of plant adaptation to serpentine (Brady et al., 2005; Kazakou et al., 2008; Turner et al., 2010). The present paper thus focusses on evolution of nickel hyperaccumulation in the genus Alyssum (Brassicaceae) that contains 51 known hyperaccumulator taxa out of $\sim 190$ species, making this the largest number of hyperaccumulating species found within a single genus (Brooks, 1998; Burge and Barker, 2010).

\section{Evolution of nickel hyperaccumulation in genus Alyssum}

Hyperaccumulator species within the genus Alyssum are widely distributed on serpentine sites across the entire Mediterranean basin, from the Iberian peninsula in the west to the Irano-Turanian region in the east (Brooks, 1987). It is not clear whether hyperaccumulation ability arose at each serpentine site independently, or whether the trait has evolved just once in an ancestral population and then spread by dispersal and range expansion to serpentine sites scattered over a broad geographical area, but this represents an excellent study group given the history of detailed taxonomic treatments of the genus (Ball and Dudley, 1993). 
Several taxa within the genus Alyssum are classed as facultative hyperaccumulators (Pollard et al., 2014), providing an opportunity to study evolution of this trait by comparing hyperaccumulating and non-accumulating ecotypes. Alyssum serpyllifolium represents the beststudied example of facultative nickel hyperaccumulation in the genus. A. halleri and $N$. caerulescens also belong to the group of facultative metallophytes, as they occur both on and off metalliferous substrates. However, A. serpyllifolium is likely to have a different evolutionary history compared with $A$. halleri and $N$. caerulescens that are most characteristically found on metal-contaminated sites created in the last two to three millennia as a result of anthropogenic disturbance (such as mining activities). Serpentine populations of Alyssum, in contrast, typically occupy isolated ultramafic outcrops that have been exposed for many millions of years, at least since the Miocene. In addition, most of the current range of A. serpyllifolium is beyond the maximum advance of the main polar ice cap during the Pleistocene glaciations (Reeves, 1992; Hewitt, 1999), unlike the ranges of A. halleri and $N$. caeruelscens, possibly offering a more stable habitat and leading to a different evolutionary trajectory. However, glacial ice covered parts of the current range of $A$. serpyllifolium, including southern Spain, certain regions in central Spain, as well as the Pyrenees and the south of France (Levin, 2013), and hence the Last Glacial Maximum cannot be entirely ruled out as a factor in the phylogenetic history of this taxon. Indeed, an influence of climatic fluctuations can be important for the population dynamics of serpentine species (Kolár et al., 2012). One scenario envisages formerly widespread metallophyte species being excluded from non-serpentine sites during post-glacial reforestation because of their low competitiveness on nonmetalliferous soils; the serpentine populations would become separated and disjunct, and because of reduced gene flow progressively differentiate owing to drift and selection. This 'depleted' (or palaeoendemic) species scenario proposed by Stebbins (Stebbins, 1942; Stebbins and Major, 1965), and considered in the serpentine context by Kruckeberg (Kruckeberg, 1954), has been shown to have taken place in the serpentine subspecies Minuartia laricifolia ssp. ophiolitica in the Alps (Moore et al., 2013) and in the Streptanthus glandulosus complex (Mayer et al., 1994). In a subsequent phase, non-serpentine progenitors can re-invade and come into secondary contact with serpentine populations (depleted species-recolonisation scenario).

The population history of $A$. serpyllifolium is likely to have been complicated by various factors. Serpentine substrates inhabited by this species represent relatively small edaphic 'islands' up to tens of kilometres in diameter (Brooks, 1987; Flynn, 2013), separated by vast stretches of a non-serpentine 'sea' with different geochemistry. As serpentine-adapted plants may not be successful competitors on nonserpentine substrates (Brooks, 1987; Elmendorf and Moore, 2007; Anacker and Harrison, 2012; Anacker, 2014), the populations occupying such serpentine islands would become isolated and could eventually diverge into separate species. Landscape and topography may also contribute to isolation of populations of A. serpyllifolium, as they often occur in mountain ranges such as Sierra de Aguas (population Carratraca-S), Sierra Bermeja de Estapona (Sierra Bermeja-S) and Serra do Careón (Barazón-S). Furthermore, ploidy difference is likely to act as an additional isolating mechanism between some populations of this species. All the Iberian populations analysed in this study are diploid, with $n=8$ (Fernandes and Queirós, 1973; Küpfer, 1974; Cecchi et al., 2013), but both diploid $n=8$ (Küpfer, 1974) and tetraploid $n=16$ (Bonnet, 1963; Puech, 1963) populations have been reported in France. All these factors may contribute to gradual divergence between individual populations, and the plants from different populations show some morphological differences. This has led to earlier proposals to raise the serpentine populations of A. serpyllifolium to the status of distinct subspecies, or even separate species (Dudley, 1986a and b,). However, analyses based on chloroplast DNA sequences have been unable to establish clearly resolved relationships between the different A. serpyllifolium populations (Cecchi et al., 2013; Flynn, 2013). In this paper, we have therefore reinvestigated the relationships between serpentine and nonserpentine populations of $A$. serpyllifolium using population-genetic approaches.

\section{MATERIALS AND METHODS}

\section{Plant material}

In this study, four serpentine and four non-serpentine populations (Figure 1 and Supplementary Table S1) were sampled from across the main range of A. serpyllifolium in the Iberian peninsula (Ball and Dudley, 1993). The four serpentine populations originate from the three serpentine areas inhabited by A. serpyllifolium: Trás-os-Montes province in northeastern Portugal (Samil-S population), Melide, Galicia (Barazón-S population) and the western Baetic Cordilleras in Andalucía (Carratraca-S and Sierra Bermeja-S populations) in Spain. The four remaining non-serpentine populations (Alhaurín-NS, León-NS, Morata-NS and Rubiá-NS) were collected from across the Iberian peninsula in varying proximity to the serpentine outcrops. Seeds were collected from fruiting plants in years between 1999 and 2012.

\section{DNA extraction}

Genomic DNA from dried plant shoots was extracted using a modification of the CTAB (cetyl trimethylammonium bromide) method (Rogers and Bendich, 1985; Porebski et al., 1997) from up to 40 individuals in each of the eight sampled A. serpyllifolium populations. The concentration of DNA in each sample was measured using a NanoDrop 2000 spectrophotometer (Thermo Scientific, Wilmington, DE, USA) following extraction.

\section{Development of microsatellite markers}

Perfect microsatellites were detected in the consensus A. serpyllifolium transcriptome assembly (manuscript in preparation) with SciRoKo version 3.4 (Kofler et al., 2007) using the following default settings: dinucleotide

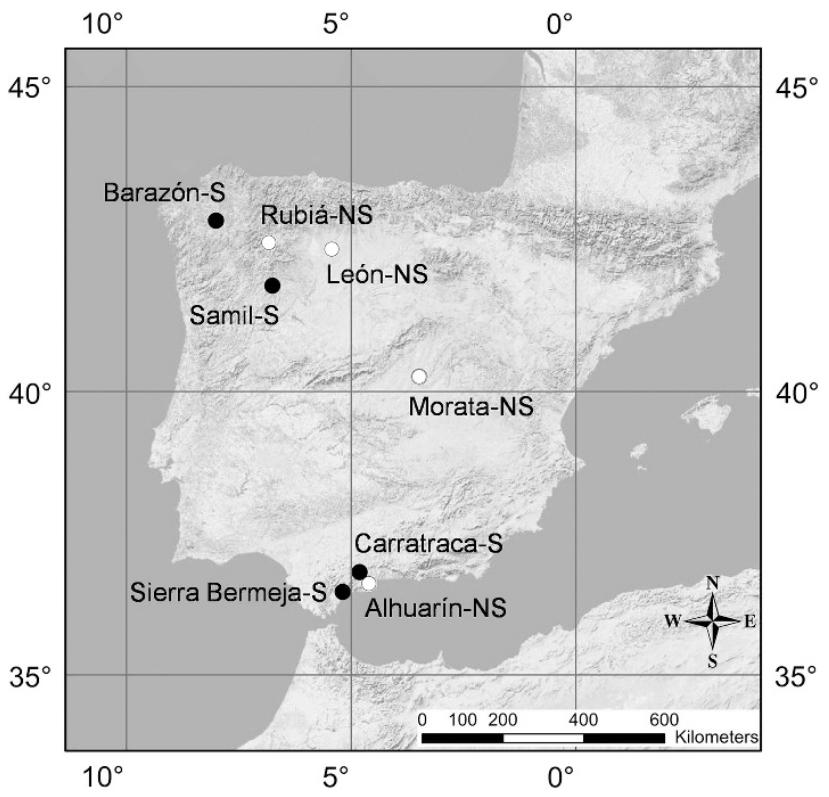

Figure 1 Distribution of the sampled populations of $A$. serpyllifolium on the Iberian peninsula. Serpentine (S) and non-serpentine (NS) populations are shown as filled and open circles, respectively. 
pattern: minimum 7 repeats; trinucleotide: minimum 5 repeats; tetra-, pentaand hexa-nucleotide: minimum 4 repeats. Out of 3942 microsatellites detected, 32 were selected based on repeat size ( 3 or 6 nucleotides, that is, no introduction of frameshift mutation), as well as the function of the target gene being considered unlikely to be important for adaptation to serpentine. Primers were then designed around each locus, and amplification success along with level of polymorphism was tested in 3-4 individuals in each population.

Each individual plant was then genotyped for eight developed microsatellites. The PCR mixture for each individual amplification reaction was assembled with the following reagents: $1.5 \mu \mathrm{l}$ of $10 \times$ buffer (New England BioLabs, Hitchin, UK), $0.3 \mu \mathrm{l}$ of $10 \mathrm{~mm}$ total dNTPs (Thermo Scientific, Hemel Hempstead, UK), $1.2 \mu \mathrm{l}$ of $25 \mathrm{~mm} \mathrm{MgCl}_{2}$ (New England BioLabs), $0.06 \mu \mathrm{l}$ of $10 \mu \mathrm{M}$ forward primer, $0.3 \mu \mathrm{l}$ of $10 \mu \mathrm{M}$ reverse primer, $0.3 \mu \mathrm{l}$ of FAM/HEX/NED labelled universal primer, $0.1 \mu \mathrm{l}$ of Taq Polymerase (New England BioLabs), $1-2 \mu \mathrm{l}$ of DNA solution (depending on the concentration, 10-100 ng contained in the reaction) and double-distilled water to $15 \mu \mathrm{l}$ total volume. Oligonucleotide primers were supplied by Eurofins MWG Operon (Ebersberg, Germany), and in addition to the gene-specific sequences listed in Supplementary Table S2, forward primers contained a $5^{\prime}$ overhang fragment of $5^{\prime}$-CACGAC GTTGTAAAACGAC- $3^{\prime}$ to facilitate incorporation of the dye-labelled universal primer in subsequent PCR cycles. PCR cycling was carried out using the following conditions: (1) initial denaturation $\left(3 \mathrm{~min}\right.$ at $\left.95^{\circ} \mathrm{C}\right)$, (2) 10 cycles of touch-down PCR $\left(30 \mathrm{~s}\right.$ at $95^{\circ} \mathrm{C}, 30 \mathrm{~s}$ at $65^{\circ} \mathrm{C}$ (reduced by one degree per cycle), $1 \mathrm{~min}$ at $\left.68^{\circ} \mathrm{C}\right),(3) 30$ cycles of standard amplification $\left(30 \mathrm{~s}\right.$ at $95^{\circ} \mathrm{C}$, $30 \mathrm{~s}$ at $55^{\circ} \mathrm{C}, 1 \mathrm{~min}$ at $68^{\circ} \mathrm{C}$ ) and (4) final extension $\left(5 \mathrm{~min}\right.$ at $\left.68^{\circ} \mathrm{C}\right)$.

\section{Genotype scoring and data analysis}

PCR-amplified fragments containing target microsatellite repeats were run on an Applied Biosystems (Foster City, CA, USA) Capillary Genetic Analyzer at the Department of Zoology, University of Oxford, UK, with GeneScan 500 LIZ Size Standard (Applied Biosystems) added as a reference and results collected using a DS-30 filter (Applied Biosystems). Microsatellite genotypes were scored manually using GeneMarker version 2.6.3 (SoftGenetics, State College, PA, USA) following the default settings for plant microsatellite scoring. In cases where a genotype could not be established with confidence, PCR products were re-run a second time. Micro-checker version 2.2.3 (Van Oosterhout et al., 2004) was then employed to test for genotyping artefacts-null alleles, stuttering and high-allele dropout levels. All of the individual genotypes were exported from MS Excel into CREATE version 1.37 (Coombs et al., 2008) that was then used to convert the data matrix into formats required for various programs.

First, departures from Hardy-Weinberg equilibrium and linkage disequilibrium were tested in Arlequin version 3.5 (Excoffier et al., 2005) and FSTAT version 2.9.3.2 (Goudet, 1995). Subsequently, two programs were used in calculating basic population genetics parameters: allele frequency, $F$-statistics, heterozygosity as well as analysis of molecular variance (AMOVA; Arlequin). The presence of an isolation-by-distance pattern (Wright, 1943) was investigated using the Mantel test with 1000 permutations (Mantel, 1967) in Genepop version 4.2 (Raymond and Rousset, 1995) by examining the correlation between log-transformed Euclidean distances between pairs of populations and linearised pairwise genetic distances $\left(F_{\mathrm{ST}} /\left(1-F_{\mathrm{ST}}\right)\right)$. The PHYLIP package version 3.69 (Felsenstein, 2005) was employed to calculate various interpopulation genetic distance metrics with bootstrapping (1000 replicates), whereas Factorial Correspondence Analysis was carried out in Genetix version 4.05 using the default settings (http://www.genetix.univ-montp2.fr/).

Bayesian analysis in Structure version 2.3.3 (Falush et al., 2003) was used to assign individuals to genetic clusters $(K)$. A model was chosen in which individuals had admixed ancestries and correlated allele frequencies to allow detection of more ancient admixture events (Falush et al., 2003). Choosing independent allele frequencies made no significant difference to the structure detected, and hence results based on correlated allele frequencies are reported here. The LocPrior clustering method implemented in the latest version of Structure was used that is not only based on the individual multilocus genotypes but also takes into account the sampling locations. The model is recommended by the authors when the genetic data are not highly informative in order to detect population structure, and was chosen because of a moderate number of microsatellite markers employed in the present study.
The number of genetic clusters $(K)$ was set from a minimum of 2 to a maximum of 10 , and five simulations were run for each $K$ value with a burn-in of 100000 and a main run of 1000000 Markov chain Monte Carlo iterations. To define the most probable value of $K$ present in the data, the method proposed by Evanno et al. (2005) was initially used that is based on an ad hoc measure $\Delta K$ that depends on the rate of change in the log probability of the data between successive values of $K$. Second, the number of true clusters was also inferred following $\mathrm{L}(K)$ over a number of clusters, and then looking for the signature of $\mathrm{L}(K)$ starting to plateau with diminished variance in $\mathrm{L}(K)$ (Pritchard et al., 2000). These calculations were carried out by Structure Harvester Web version 0.6.94 (Earl and vonHoldt, 2012) that also generated CLUMPP input files. Subsequently, cluster assignments from across the replicate runs were aligned and averaged using CLUMPP version 1.1 (Jakobsson and Rosenberg, 2007) run with the Greedy algorithm and 1000 permutations of randomised input order. Resulting final cluster assignments were visualised using the program DISTRUCT version 1.1 (Rosenberg, 2004).

\section{Locus selection and primer development}

For sequence analyses of selection we chose two loci involved in metal hyperaccumulation and homeostasis in other plant species: natural resistance associated macrophage protein 4 (NRAMP4) and iron-regulated protein 1 (IREG1). On the other hand, 6B-interacting protein 1-like 1 (ASIL1) was selected as a reference gene for comparisons with NRAMP4 and IREG1, as ASIL1 is not expected to play a specific role in ecological adaptation in Alyssum as it is a transcriptional repressor of seed maturation genes in germinating seeds and seedlings in Arabidopsis (Gao et al., 2009). Primers for these genes were developed based on A. serpyllifolium transcriptome sequences of these genes using the PrimerDesignM web server (Yoon and Leitner, 2015) with default settings. For both IREG1 and NRAMP4 genes, amplification primers were also used as sequencing primers (Supplementary Table S3), but in the neutral gene ASIL1 a different reverse primer was used for amplification (ASIL1 R1) and sequencing (ASIL1 INTF1). Sequenced regions in both IREG1 and NRAMP4 were found to contain putative introns, $82 \mathrm{bp}$ long in IREG1 and $145 \mathrm{bp}$ long in NRAMP4, that were excluded from the analyses described below, unless otherwise stated.

\section{Gene fragment amplification and Sanger sequencing}

PCR mixture $(30 \mu \mathrm{l})$ for each sample was assembled with the following reagents: $3 \mu \mathrm{l}$ of $10 \times$ buffer (New England BioLabs), $0.6 \mu \mathrm{l}$ of $10 \mathrm{~mm}$ total dNTPs (Thermo Scientific), $2.4 \mu \mathrm{l}$ of $25 \mathrm{~mm} \mathrm{MgCl}_{2}$ (New England BioLabs), $0.6 \mu \mathrm{l}$ of $10 \mu \mathrm{M}$ forward primer, $0.6 \mu \mathrm{l}$ of $10 \mu \mathrm{m}$ reverse primer, $0.2 \mu \mathrm{l}$ of Taq Polymerase (New England BioLabs), $1 \mu \mathrm{l}$ of DNA solution (25-250 ng) and $21.6 \mu \mathrm{l}$ of double-distilled water. In the case of ASIL1, $4.8 \mu \mathrm{l}$ of $5 \mathrm{~m}$ betaine was added to a final concentration of $0.8 \mathrm{M}$, with concomitant reduction of the water volume, to increase primer annealing specificity and fragment amplification rate (Ralser et al., 2006). PCR cycling was carried out under the following conditions: (1) initial denaturation $\left(3 \mathrm{~min}\right.$ at $\left.95^{\circ} \mathrm{C}\right)$; (2) 10 cycles of touch-down PCR $(30 \mathrm{~s}$ at $95^{\circ} \mathrm{C}, 30 \mathrm{~s}$ at $65^{\circ} \mathrm{C}$ (reduced by one degree per cycle), $1 \mathrm{~min}$ at $68^{\circ} \mathrm{C}$ ); (3) 33 cycles (IREG1) or 40 cycles (NRAMP4) of amplification $\left(30 \mathrm{~s}\right.$ at $95^{\circ} \mathrm{C}, 1 \mathrm{~min}$ at $45-55^{\circ} \mathrm{C}, 4 \mathrm{~min}$ at $68^{\circ} \mathrm{C}$ ), or in the case of ASIL 1 the first 10 cycles carried out at $42{ }^{\circ} \mathrm{C}$ and the final 30 cycles with $50^{\circ} \mathrm{C}$ annealing temperature to facilitate permissive primer binding and target region amplification in the initial steps of the PCR reaction; and (4) final extension step $\left(5 \mathrm{~min}\right.$ at $\left.68^{\circ} \mathrm{C}\right)$. PCR products of correct size, high purity and concentration were then sequenced at the DNA Sequencing Unit, Department of Zoology, University of Oxford, on an ABI $3730 \times 1$ DNA Analyzer (Applied Biosystems).

\section{Data analysis}

Raw ABI output chromatograms were examined and exported to the FASTA format using FinchTV software version 1.4 (Perkin-Elmer, Beaconsfield, UK). Consensus DNA contigs from combined forward primer and reverse primer sequencing results were created manually in MEGA (Tamura et al., 2013) from sequences trimmed on base call quality. DnaSP version 5 (Librado and Rozas, 2009) was employed to calculate the relevant population-genetic parameters, carry out tests for selection and phase the diploid sequences with the PHASE algorithm (Stephens et al., 2001). AMOVA was performed in Arlequin version 
3.5 (Excoffier et al., 2005) and gene trees based on Nei's $D_{\mathrm{A}}$ (Nei et al., 1983) were prepared in POPTREE2 (Takezaki et al., 2010) with 1000 bootstrap replicates.

\section{RESULTS}

Genetic diversity and population structure

To analyse population structure and degree of isolation between the sampled populations of Alyssum serpyllifolium, we genotyped eight microsatellite loci in 272 individuals from four serpentine (Barazón-S, Carratraca-S, Samil-S, Sierra Bermeja-S) and four non-serpentine populations (Alhaurín-NS, León-NS, Morata-NS, Rubiá-NS; see Figure 1 and Supplementary Table S1). This revealed between 4 and 12 alleles per locus, with a mode of 5 alleles. No evidence for genotyping artefacts, such as null alleles, was found with Microchecker (Van Oosterhout et al., 2004). All microsatellite loci were in linkage equilibrium.

Within-population gene diversity $\left(H_{\mathrm{o}}\right)$ ranged from 0.33 to 0.62 (average $H_{\mathrm{o}}=0.48$ ) and did not differ significantly between serpentine (average $H_{0}=0.50$ ) and non-serpentine (average $H_{0}=0.46$ ) popula-

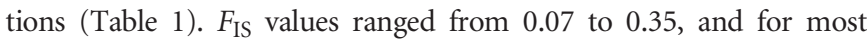
populations were significantly different from 0 , based on 1000 permutations (Table 1), pointing to a non-negligible degree of inbreeding in A. serpyllfolium. These results are in line with expectations for serpentine endemics, reflecting small effective population sizes and small distribution ranges and, as a consequence, low genetic diversity and high levels of inbreeding (Anacker et al., 2011). On the other hand, we found significant $F_{I S}$ in only two of the four serpentine A. serpyllfolium populations studied (Table 1).

The results show relatively high levels of population differentiation, with overall $F_{\mathrm{ST}}=0.23$ (95\% confidence interval 0.17-0.29). AMOVA results indicated that $23.7 \%$ of all genetic variation was partitioned between populations, whereas $16.7 \%$ and $59.6 \%$ partitioned within populations among and within individuals, respectively. When populations are grouped into serpentine (S) and non-serpentine (NS) ecotypes, only a small proportion of variation is accounted for by differentiation between these groups in microsatellite genetic diversity (Table 2).

Population-genetic structure analysis with Structure software (Falush et al., 2003) revealed two optimal numbers of genetic clusters $(K): K=4$ (as per $\Delta K$ : Supplementary Figure $S 1$ ) and $K=8$ (as per $\mathrm{LnP}(\mathrm{D})$ : Supplementary Figure S2). $K=4$ results show a trend towards

Table 1 Population diversity and inbreeding coefficient $\left(F_{\mid \mathrm{S}}\right)$ in samples of $n$ individuals genotyped for eight microsatellite loci in eight populations of Alyssum serpyllifolium

\begin{tabular}{lcccccc}
\hline Population & $\mathrm{n}$ & $\mathrm{F}_{\text {IS }}$ & $\mathrm{H}_{0}$ & s.d. & $\mathrm{H}_{e}$ & s.d. \\
\hline Alhaurín-NS & 36 & $0.35^{*}$ & 0.33 & 0.21 & 0.51 & 0.22 \\
León-NS & 22 & $0.22^{*}$ & 0.51 & 0.26 & 0.65 & 0.23 \\
Morata-NS & 30 & $0.22^{*}$ & 0.55 & 0.14 & 0.70 & 0.09 \\
Rubiá-NS & 41 & $0.24^{*}$ & 0.44 & 0.21 & 0.58 & 0.13 \\
Average for NS & 32 & 0.2575 & 0.4575 & 0.205 & 0.61 & 0.1675 \\
Barazón-S & 35 & 0.07 & 0.40 & 0.27 & 0.43 & 0.25 \\
Carratraca-S & 33 & $0.27^{*}$ & 0.48 & 0.24 & 0.65 & 0.15 \\
Samil-S & 36 & $0.16^{*}$ & 0.62 & 0.14 & 0.73 & 0.11 \\
Sierra Bermeja-S & 36 & 0.08 & 0.51 & 0.20 & 0.55 & 0.18 \\
Average for S & 35 & 0.145 & 0.5025 & 0.2125 & 0.59 & 0.1725 \\
\hline
\end{tabular}

Abbreviations: NS, non-serpentine; S, serpentine.

$F_{I S}$ values deviating significantly $(P<0.05)$ from 0 are labelled with an asterisk $\left(^{*}\right)$ grouping together geographically close populations of the same ecotype, whereas $K=8$ simply place each population in its own separate cluster (Figure 2). Admixture proportions of individuals in different populations varied in the $K=4$ solution. Individuals in NS populations (northern Rubiá-NS and southern Alhaurín-NS) belonged to a single cluster each (pink and green clusters, respectively), and so did the S populations Sierra Bermeja-S and Carratraca-S in the south (blue cluster). The other four populations showed varying degrees of admixture. The northern Barazón-S and Samil-S populations mostly belonged to the fourth cluster (brown), with more (Samil-S) or less (Barazón-S) admixture from Alhaurín-NS green cluster. The northern and central NS populations Morata-NS and León-NS contained the highest admixture from Alhaurín-NS green cluster, in addition to smaller admixture from Samil-S and Barazón-S brown cluster and Rubiá-NS pink cluster (only in León-NS).

To investigate whether the pattern of isolation by distance could be detected over all populations, a Mantel test (Mantel, 1967) was carried out on the Weir and Cockerham (1984) $F_{\text {ST }}$ pairwise distance matrix (Supplementary Table S4). This did not reveal any direct correlation, and the number of populations within each ecotype was too small to allow isolation-by-distance testing for S and NS populations separately within them. No consensus neighbour-joining tree could be obtained with reliable branch support values based on Nei's $D_{\mathrm{ST}}$ distance metric (Nei, 1987), and no population structure could be detected using factor analysis in GENETIX (data not shown). Taken together, our data indicate that the analysed $A$. serpyllifolium populations appear to be more or less equidistant from each other and do not cluster according to $\mathrm{S}$ and NS ecotypes.

Patterns of sequence diversity at loci putatively involved in metal hyperaccumulation

Genetic diversity across $\mathrm{S}$ and NS populations of A. serpyllifolium was analysed in three genes (Table 3), one of which, ASIL1, was used as a reference locus unlikely to be involved in evolution of the nickel hyperaccumulation trait, whereas the two other loci, NRAMP4 and IREG1, have established roles in metal hyperaccumulation and homeostasis in other plant species.

In individual A. serpyllifolium populations, between 5 and 13 individuals were sequenced for ASIL1, 10 to 12 individuals for IREG1 and 6 to 11 individuals for NRAMP4, with the exception of the LeónNS population, for which only 2 individuals were successfully sequenced (Table 3). For this reason, the León-NS population was excluded from most of the analyses focussing on NRAMP4. Overall, similar levels of sequence diversity were obtained for the two candidate genes and the reference gene (Table 3 ). Within the populations, genetic diversity varied widely in all three genes, with no clearly

Table 2 Percentage of variation in microsatellites and three genes accounted for by differentiation between ecotypes and populations, as revealed by AMOVA analyses

\begin{tabular}{lccc}
\hline & $\begin{array}{c}\text { Among S and NS } \\
\text { ecotypes }\end{array}$ & $\begin{array}{c}\text { Among populations within } \\
\text { ecotypes }\end{array}$ & $\begin{array}{c}\text { Within } \\
\text { populations }\end{array}$ \\
\hline Microsatellites & 4.97 & 20.59 & 74.45 \\
ASIL1 & 4.5 & 41.1 & 54.4 \\
IREG1 & 64.5 & 16.8 & 18.7 \\
NRAMP4 & 89.7 & 4.6 & 5.6
\end{tabular}

Abbreviations: AMOVA, analysis of molecular variance; NS, non-serpentine; S, serpentine. Eight populations of Alyssum serpyllifolium were split into two groups, $\mathrm{S}$ and NS, with four populations in each group, as defined in Table 1. 
discernible pattern. Tests for selection did not detect any departures from neutrality in any of the populations (Table 3).

Interestingly, the two genes putatively involved in metal hyperaccumulation revealed striking differentiation between $S$ and NS populations, as measured by $F_{\mathrm{ST}}$ and $D_{\mathrm{A}}$, in contrast to low differentiation at ASIL1 and the microsatellites (Table 2 and Supplementary Tables S4 and S5). For both NRAMP4 and IREG1, two strongly supported subclades grouping $S$ and NS populations were reconstructed based on Nei et al. (1983) $D_{\mathrm{A}}$ (Figure 3 and Supplementary Figure S3). Conversely, no well-supported population tree (all bootstrap support values $<60 \%$ ) could be recovered based on
ASIL1, with S and NS populations intermixed on the tree (Figure 3 and Supplementary Figure S3).

Pairwise $F_{\mathrm{ST}}$ values for ASIL1 did not vary significantly across population pairs regardless of their $S$ or NS origin (Supplementary Table S5). Conversely, for NRAMP4, pairwise comparisons of the $\mathrm{S}$ and NS populations resulted in $F_{\mathrm{ST}}>0.9$, whereas for pairwise comparisons within $\mathrm{S}$ populations much lower differentiation was found, with $F_{\mathrm{ST}}$ typically $<0.125$, with the exception of Barazón-S, where NRAMP4 appears to have undergone additional longer sequence evolution than in other $S$ populations (Supplementary Table S5).

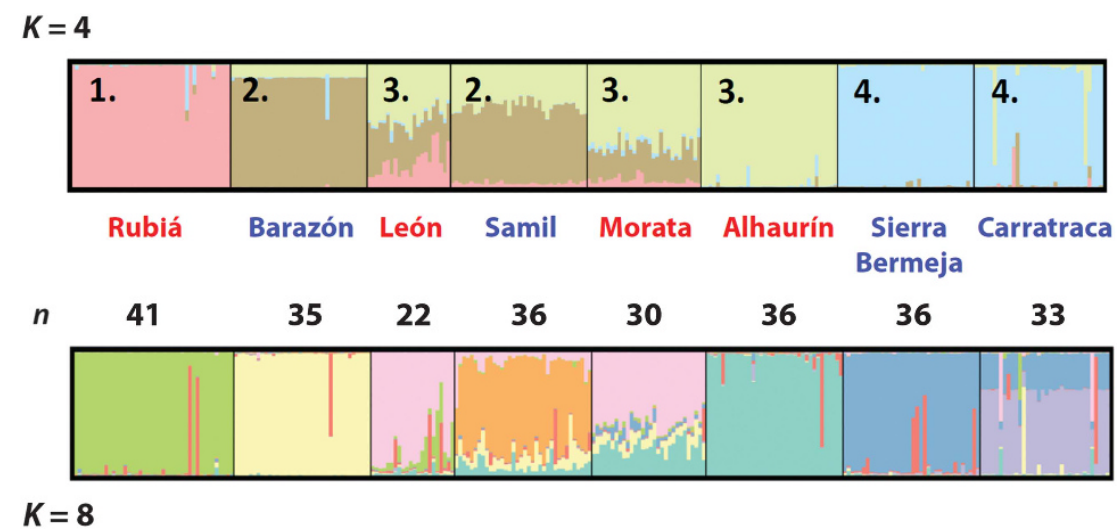

Figure 2 Assignment of genotypes of individuals in the eight $A$. serpyllifolium populations to either 4 (top) or 8 (bottom) genetic clusters as defined to be most likely by Structure. Serpentine populations are indicated in blue and non-serpentine in red. $n$, number of sampled individuals in each population.

Table 3 Summary statistics for DNA sequence polymorphism analysis in three nuclear genes

\begin{tabular}{|c|c|c|c|c|c|c|c|c|c|}
\hline & \multirow[t]{2}{*}{ All } & \multicolumn{4}{|c|}{ Serpentine populations } & \multicolumn{4}{|c|}{ Non-serpentine populations } \\
\hline & & Barazón & Carratraca & Samil & Sierra Bermeja & Alhaurín & León & Morata & Rubiá \\
\hline \multicolumn{10}{|l|}{ ASIL1 (length = 735 bp) } \\
\hline Sample size & 71 & 10 & 13 & 8 & 6 & 10 & 9 & 10 & 5 \\
\hline Haplotype diversity & 0.965 & 0.189 & 0.963 & 0.958 & 0.894 & 0.695 & 0.993 & 0.968 & 0.800 \\
\hline Nucl. diversity (non-synonym.) & 0.0032 & 0.033 & 0.047 & 0.175 & 0.282 & 0.301 & 0.253 & 0.139 & 0.253 \\
\hline Nucl. diversity (synonymous) & 0.0123 & 0 & 1.562 & 0.651 & 0.541 & 0.287 & 1.449 & 1.315 & 0.349 \\
\hline Tajima's D (all sites) & $-1.85^{*}$ & -0.59 & 0.86 & -0.16 & 0.93 & 0.94 & 0.97 & 0.86 & 0.53 \\
\hline Fay and Wu's $H$ (all sites) & -0.911 & 0.17 & -0.37 & -0.77 & -0.70 & 0.59 & -1.83 & -0.02 & 0.89 \\
\hline \multicolumn{10}{|l|}{ IREGI (length $=668 \mathrm{bp})$} \\
\hline Sample size & 86 & 10 & 12 & 10 & 10 & 12 & 10 & 11 & 11 \\
\hline Haplotype diversity & 0.834 & 0 & 0.236 & 0.958 & 0.911 & 0.772 & 0.363 & 0.005 & 0 \\
\hline Nucl. diversity (non-synonym.) & 0.0033 & 0 & 0.019 & 0.244 & 0.142 & 0.055 & 0.112 & 0.079 & 0 \\
\hline Nucl. diversity (synonymous) & 0.0117 & 0 & 0.069 & 0.846 & 1.050 & 0.601 & 0.044 & 0.525 & 0 \\
\hline Tajima's D (all sites) & -1.49 & - & -1.20 & 1.12 & 1.76 & -0.93 & -1.78 & 0.01 & - \\
\hline Fay and Wu's $H$ (all sites) & -1.77 & - & 0.22 & -2.52 & -2.47 & -3.75 & 0.55 & -0.48 & - \\
\hline \multicolumn{10}{|l|}{ NRAMP4 (length = $1180 \mathrm{bp})$} \\
\hline Sample size & 65 & 6 & 11 & 8 & 11 & 10 & 2 & 10 & 7 \\
\hline Haplotype diversity & 0.809 & 0.848 & 0.574 & 0.400 & 0.363 & 0.484 & - & 0.233 & 0.615 \\
\hline Nucl. diversity (non-synonym.) & 0.0035 & 0.122 & 0.024 & 0 & 0 & 0.024 & - & 0.030 & 0.056 \\
\hline Nucl. diversity (synonymous) & 0.0134 & 0.314 & 0.269 & 0.105 & 0.102 & 0.084 & - & 0 & 0.067 \\
\hline Tajima's $D$ (all sites) & 0.42 & 0.32 & -0.95 & 0.33 & -1.14 & -0.16 & - & -0.45 & 0.32 \\
\hline Fay and Wu's $H$ (all sites) & -0.07 & 0.67 & -1.01 & 0.29 & 0.26 & 0.42 & - & 0.20 & -1.05 \\
\hline
\end{tabular}

Abbreviations: non-synonym., non-synonymous; Nucl., nuclear.

${ }^{*} P<0.05$. 


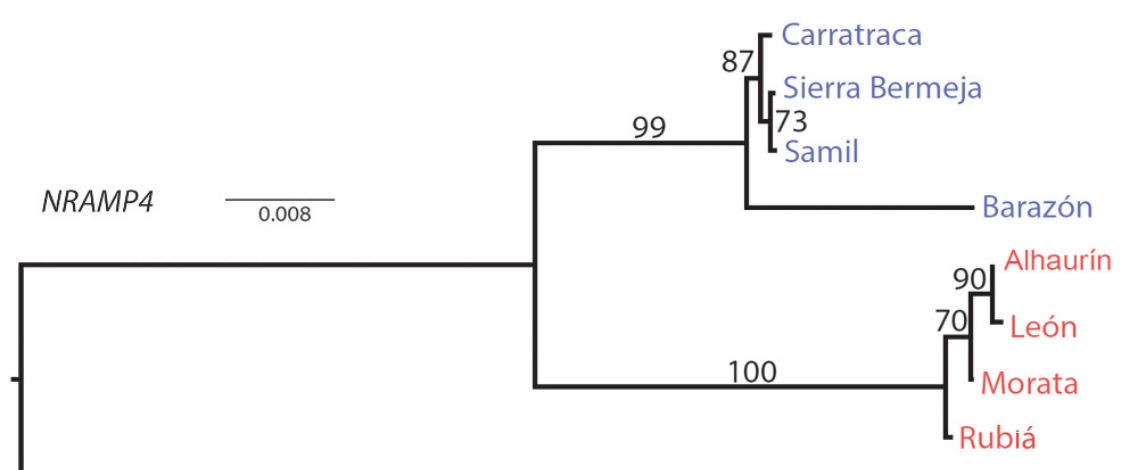

Clypeola

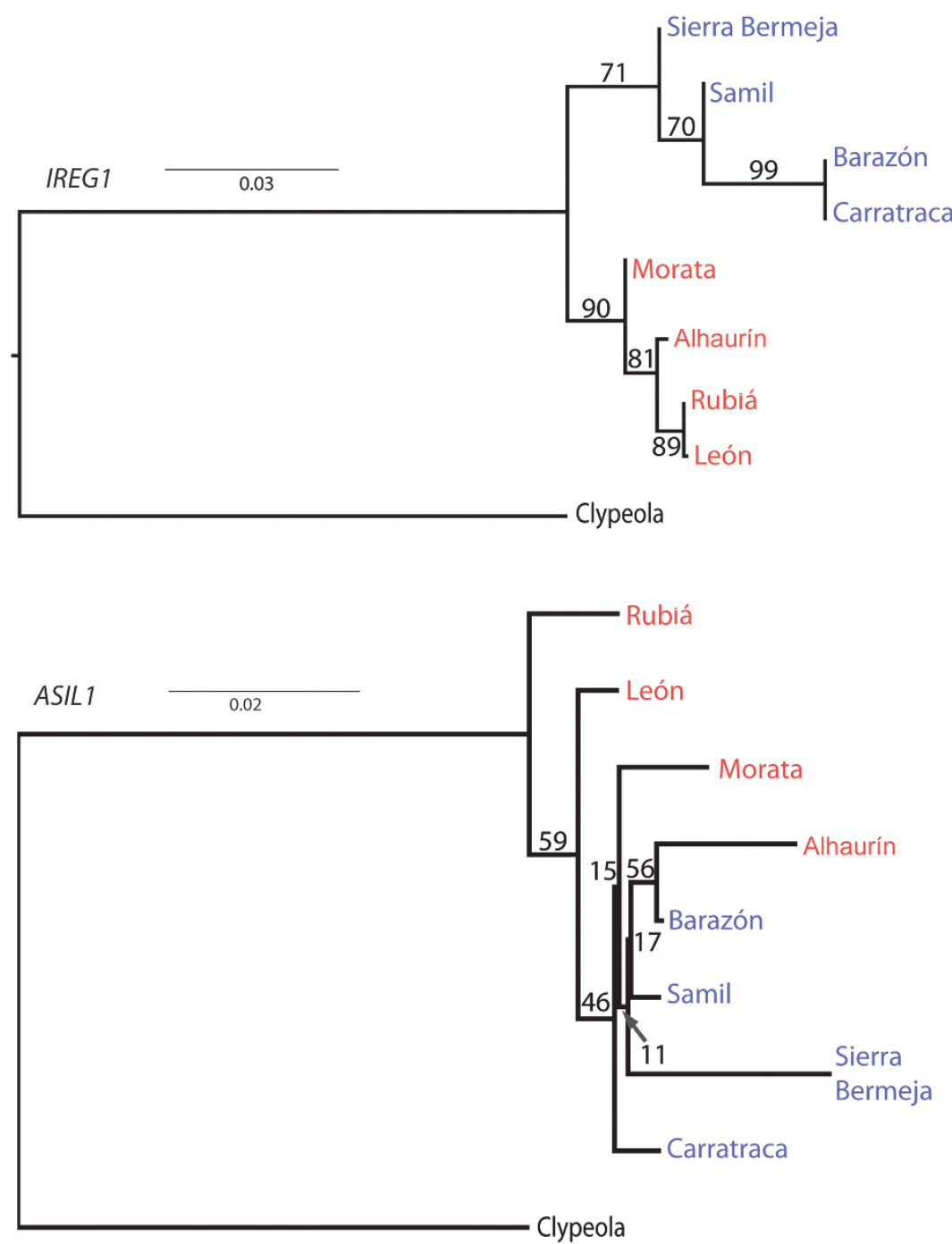

Figure 3 Gene trees based on net population divergence $\left(D_{A}\right)$ at all sites for NRAMP4, IREG1 and ASIL1 genes. For trees based on silent sites see Supplementary Figure S3. Numbers on the branches show percentage support over 1000 bootstrap replicates. Serpentine populations are in blue and nonserpentine populations in red.

AMOVA results (Table 2) confirm the high degree of shared genetic variation in the two candidate genes in populations of the same ecotype. When populations are grouped into S and NS ecotypes, the overwhelming percentage $(89.7 \%$ in NRAMP4 and $64.5 \%$ in IREG1) of genetic variation is split between the two groups, whereas the rest is evenly distributed among populations within groups and within populations. The opposite pattern is found for the reference gene ASIL1 as well as for microsatellites, where S vs NS population grouping explained a very small proportion of overall genetic variation (Table 2).

Both candidate genes also contained a significant proportion of single-nucleotide polymorphisms (SNPs) fixed or nearly fixed between 
the two ecotypes, with serpentine populations often featuring fixed derived genetic variants (Table 4). In particular, NRAMP4 contains eight SNPs fixed for distinct alleles in S and NS populations. Four of these SNPs encode non-synonymous changes, and in all cases the serpentine alleles are derived relative to the non-accumulators Arabidopsis thaliana and Clypeola jonthlaspi (the latter a member of the same clade within the tribe Alysseae as A. serpyllifolium: Rešetnik et al., 2013; Španiel et al., 2015), and hence could be of adaptive importance. In particular, the Asp $\rightarrow$ Asn amino acid replacement at position 1190 leads to a change from an amino acid with acidic to neutral side-chain properties in the serpentine populations that may influence protein function. Two further synonymous NRAMP4 SNPs are nearly fixed between the ecotypes: at one SNP (position 343) the serpentine allele is segregating in Rubiá-NS, and at another SNP (position 1222) the serpentine allele is not fixed in Barazón-S. Similarly, IREG1 contained six SNPs fixed or nearly fixed between the $\mathrm{S}$ and NS ecotypes, four of which were non-synonymous (Table 4 ).

\section{DISCUSSION}

Our analyses revealed considerable genetic diversity in A. serpyllifolium populations regardless of their S or NS origin. Such a relatively even distribution of genetic diversity is not expected if either $S$ or NS populations were founded only recently. In particular, our results rule out a scenario of recent colonisation of serpentine environments by local migrants from non-serpentine populations, and indicate that both $S$ and NS populations of A. serpyllifolium have existed for a long time. This is consistent with a relatively minor impact of glaciations on A. serpylifolium populations in parts of south-western Europe beyond the maximum advance of the main polar ice cap during the Pleistocene glaciations (Reeves, 1992; Hewitt, 1999).

Previous studies of the population genetics of species harbouring metallicolous and non-metallicolous populations have often speculated that, given the scenario of local evolution of metallicolous populations from relatively metal-tolerant, low-frequency genotypes present in non-metallicolous populations, a founder effect may have been present in metallicolous populations when they originally diverged from the source populations (Pauwels et al., 2005), resulting in lower genetic diversity in the metallicolous populations. However, no differences in genetic diversity between metallicolous and nonmetallicolous populations have been consistently found in the species investigated to date (Vekemans and Lefebvre, 1997; Quintela-Sabarís et al., 2010), such as A. halleri (Pauwels et al., 2005), A. bertolonii (Mengoni et al., 2003) and M. laricifolia ssp. ophiolitica (Moore et al., 2013), and neither have they been found here (Table 2). However, the bottlenecks in question would need to have been quite recent to stand out in this way, and gene flow and accumulation of new mutations would later erode the signal of any putative bottlenecks (Vekemans and Lefèbvre, 1997).

Our results reveal relatively high levels of population differentiation in A. serpyllifolium, with overall $F_{\mathrm{ST}}=0.23$ ( $95 \%$ confidence interval $0.17-$ 0.29). Moderate-to-high values of $F_{\mathrm{ST}}$ in A. serpyllifolium are typical of values from other taxa endemic to specific substrates, such as Primulina tabacum (0.3936: Ni et al., 2006), Jurinea pinnata (0.374: SalmerónSánchez et al., 2014a) or Convolvulus boisseri (0.395: Salmerón-Sánchez et al., 2014b). An even higher $F_{\mathrm{ST}}$ range was encountered between western Swiss populations of the model hyperaccumulator N. caerulescens, in which $F_{\mathrm{ST}}$ reached an average of 0.591 (Besnard et al., 2009). The values observed here provide evidence for moderate-to-low gene flow between the populations of A. serpyllifolium, probably determined by both ecological (serpentine 'islands' of endemism) and topographical barriers, such as mountains and canyons, resulting in fragmentation of the species' range. Consistent with this, AMOVA indicated that population divergence accounts for about one-quarter of all genetic variation in A. serpyllifolium. Similar between-population partitioning of genetic variation $(22 \%)$ was found in an inter-simple sequence repeat study of four populations of the nickel hyperaccumulator Alyssum lesbiacum on the island of Lesbos (Adamidis et al., 2014). In contrast, another Alyssum hyperaccumulator, A. bertolonii, had over a half (51\%) of its genetic variation partitioned between populations in a study of 9 populations in Italy genotyped with chloroplast simple sequence repeats

Table 4 Summary of SNPs fixed or nearly fixed among S and NS populations of Alyssum serpyllifolium in IREG1 and NRAMP4 genes

\begin{tabular}{|c|c|c|c|c|c|}
\hline Position of candidate SNP & Fixed in all S populations? & Present in NS populations? & Substitution $(N S \rightarrow S)$ & Substitution effect & $S$ allele derived? \\
\hline \multicolumn{6}{|l|}{ IREGI } \\
\hline $493^{a}$ & Segregating in SB and Samil & No & $C \rightarrow A$ & Ser $\rightarrow$ Arg & No \\
\hline 504 & Absent in SB, segregating in Samil & No & $A \rightarrow G$ & - & Yes \\
\hline 509 & Segregating in SB and Samil & No & $\mathrm{T} \rightarrow \mathrm{C}$ & $\mathrm{Val} \rightarrow \mathrm{Ala}$ & Yes \\
\hline 516 & Segregating in SB and Samil & No & $\mathrm{G} \rightarrow \mathrm{T}$ & Arg $\rightarrow$ Ser & No \\
\hline 556 & Segregating in SB and Samil & No & $C \rightarrow A$ & Leu $\rightarrow$ Ile & No \\
\hline $681^{a}$ & Segregating in SB and Samil & No & $\mathrm{G} \rightarrow \mathrm{A}$ & - & Yes \\
\hline \multicolumn{6}{|l|}{ NRAMP4 } \\
\hline 343 & Yes & Segregating in Rubiá & $\mathrm{C} \rightarrow \mathrm{G}$ & - & Yes \\
\hline 511 & Yes & No & $\mathrm{T} \rightarrow \mathrm{G}$ & - & Yes \\
\hline 519 & Yes & No & $\mathrm{C} \rightarrow \mathrm{G}$ & $\mathrm{Ala} \rightarrow$ Gly & Yes \\
\hline 527 & Yes & No & $\mathrm{G} \rightarrow \mathrm{A}$ & $\mathrm{Val} \rightarrow \mathrm{Ile}$ & Yes \\
\hline 571 & Yes & No & $\mathrm{C} \rightarrow \mathrm{T}$ & - & No \\
\hline 976 & Yes & No & $\mathrm{T} \rightarrow \mathrm{C}$ & - & No \\
\hline 1019 & Yes & No & $A \rightarrow C$ & $\mathrm{Ile} \rightarrow \mathrm{Leu}$ & Yes \\
\hline 1060 & Yes & No & $\mathrm{C} \rightarrow \mathrm{T}$ & - & Yes \\
\hline 1190 & Yes & No & $\mathrm{G} \rightarrow \mathrm{A}$ & Asp $\rightarrow$ Asn & Yes \\
\hline 1222 & Segregating in Barazón & No & $\mathrm{T} \rightarrow \mathrm{C}$ & - & No \\
\hline
\end{tabular}

Abbreviations: NS, non-serpentine; S, serpentine; SB, Sierra Bermeja; SNP, single-nucleotide polymorphism.

Ancestral status of the alleles was determined based on Clypeola jonthlaspi and Arabidopsis thaliana outgroups.

${ }^{a}$ Outlier SNP not detected in the original RNA-Sequencing data set. 
(Mengoni et al., 2003). Between-population variation found in a chloroplast restriction fragment length polymorphism-based study of 28 populations $A$. halleri (Pauwels et al., 2005) was even higher and amounted to $68 \%$. Thus, the levels of between-population genetic variation revealed in our study are not dissimilar to those found in other metal hyperaccumulator species, indicating that evolution of metal hyperaccumulation in A. serpyllifolium is likely to be representative of the processes driving the evolution of the trait in other hyperaccumulator species as well.

Our analyses based on microsatellites and DNA sequence data from the ASIL1 reference locus demonstrate that differentiation between $\mathrm{S}$ and NS ecotypes accounts for very little genetic diversity in A. serpyllifolium populations, indicating that there is little differentiation between the ecotypes across the genome. In contrast, two genes putatively involved in metal hyperaccumulation, NRAMP4 and IREG1, show far higher differentiation between $\mathrm{S}$ and NS ecotypes. NRAMP4 expression appears to correlate positively with $\mathrm{Ni}$ tolerance (Oomen et al., 2009; Halimaa et al., 2014) in N. caerulescens, one of the metalhyperaccumulating species of Brassicaceae that can accumulate $\mathrm{Ni}$ as well as $\mathrm{Zn}$ and $\mathrm{Cd}$. In both A. thaliana and N. caerulescens, NRAMP4 has been shown to encode a tonoplast-localised $\mathrm{Zn}, \mathrm{Fe}, \mathrm{Mn}$ and $\mathrm{Cd}$ transporter (Thomine et al., 2000, 2003; Lanquar et al., 2005, 2010; Pottier et al., 2015). In particular, ectopic overexpression of NRAMP4 in transgenic $A$. thaliana promotes $\mathrm{Zn}$ and $\mathrm{Cd}$ remobilisation from root vacuoles and decreased metal accumulation in the root (Pottier et al., 2015), thus acting in a process expected to operate at a high level in hyperaccumulator species that preferentially translocate metals to the shoot. The NRAMP4 homologue from the serpentine $\mathrm{Ni}$ hyperaccumulator $T$. japonicum has been shown to transport $\mathrm{Ni}$ specifically when heterologously expressed in yeast (Mizuno et al., 2005), and hence this transporter may be directly implicated in $\mathrm{Ni}$ transport and/or sequestration in plants specifically adapted to serpentine substrates. Expression of IREG1, another membranelocalised metal-ion transporter, has also been shown to be important for nickel and cobalt detoxification in A. thaliana (Kirchner, 2009), consistent with increased nickel tolerance in IREG1-overexpressing transgenic lines and increased nickel sensitivity in IREG1 knockout lines. In addition, a newly characterised IREG family member in the nickel hyperaccumulator Psychotria gabrielliae (Rubiaceae) appears to confer increased nickel tolerance, possibly by enhancing vacuolar accumulation of $\mathrm{Ni}$ (Merlot et al., 2014). Taken together, we hypothesise that both NRAMP4 and IREG1 are likely to be of high adaptive significance for the nickel-hyperaccumulation ability of A. serpyllifolium. Conversely, ASIL1, selected as a reference gene for comparisons with NRAMP4 and IREG1, is a transcriptional repressor of seed maturation genes in germinating seeds and seedlings in Arabidopsis (Gao et al., 2009), and is thus unlikely to play a significant role in nickel tolerance and hyperaccumulation in Alyssum.

Stronger differentiation between $\mathrm{S}$ and NS ecotypes at NRAMP4 and IREG1, compared with ASIL1 and microsatellites, is consistent with diversifying selection in NRAMP4 and IREG1 genes driven by local adaptation to $\mathrm{S}$ and NS environments. Furthermore, local adaptation at these genes is supported by the presence of derived SNPs, including amino acid replacements that are fixed or nearly fixed in serpentine populations, whereas non-serpentine populations are fixed for the ancestral alleles (Table 4). The question of when and how these putatively adaptive alleles spread across the serpentine populations of A. serpyllifolium is of considerable interest, as this may shed light on the evolution of nickel hyperaccumulation. If the spread were recent $\left(<2 N_{\mathrm{e}}\right.$ generations ago), it would be expected to leave characteristic footprints of a selective sweep, such as reduced variation in and around the loci concerned in serpentine populations. However, no deviations from neutrality were detected in any of the populations, indicating that local adaptation to serpentine conditions in NRAMP4 and IREG1 genes may have occurred relatively early in the history of the species complex. This is consistent with the distribution of serpentine A. serpyllifolium populations on relatively old ultramafic outcrops that have been exposed for many millions of years.

In summary, the present results from the population-genetic analysis of $A$. serpyllifolium across the Iberian peninsula suggests that the $\mathrm{S}$ and NS ecotypes can be regarded as belonging to the same species complex and do not warrant description as distinct taxonomic entities. Although earlier work has demonstrated that the serpentine populations show particular morphological characteristics when growing on these substrates in situ, and that they display a much higher degree of nickel tolerance than the non-serpentine populations when tested under common-garden conditions, the distinctiveness of these ecotypes is not supported by the results of the microsatellite analysis. Rather, all eight populations tested were differentiated from each other to an approximately equal extent, with evidence of a significant degree of inbreeding probably indicative of a relatively long history of isolation of these populations. At the level of DNA polymorphism, however, two candidate genes putatively involved in nickel hyperaccumulation showed signatures of adaptive evolution that may represent an integral part of the mechanism of local adaptation to serpentine substrates.

\section{CONCLUSIONS}

Our results demonstrate that divergence between S and NS ecotypes of A. serpyllifolium is no greater than among populations of the same ecotype. This does not support earlier suggestions that $\mathrm{S}$ and NS A. serpyllifolium populations represent separate species (Dudley, 1986a, b). Although earlier work has demonstrated that the serpentine populations show particular morphological characteristics when growing on these substrates in situ (Dudley, 1986a, b), and that they display a much higher degree of nickel tolerance than the nonserpentine populations when tested under common-garden conditions (Brooks et al., 1981), the distinctiveness of these ecotypes is detectable only at the loci putatively involved in the metal hyperaccumulation trait. Selective pressure at these loci to adapt to highly distinct conditions at S and NS sites has resulted in strong differentiation, with many synonymous and non-synonymous mutations fixed between the two ecotypes. Contrary to this, no such differentiation was detected elsewhere in the genome; all eight populations tested were differentiated from each other to an approximately equal extent and contained similar levels of genetic diversity, providing no support to the hypothesis that populations of one ecotype originated from local populations of the other ecotype. We conclude that adaptation to $\mathrm{S}$ and NS environments in A. serpyllifolium populations probably had a long history, but affected only the genes involved in evolution of metal tolerance and hyperaccumulation, whereas patterns of polymorphism in the rest of the genome have been dominated by geographic isolation of these populations. Expanding this analysis to a greater number of genes and populations in the future will help to identify more genes involved in evolution of metal hyperaccumulation and more precisely reconstruct the history of evolution of this peculiar trait.

\section{DATA ARCHIVING}

The DNA sequence data in this paper are available under GenBank accession numbers KX592209-KX592426. Microsatellite genotypes are available from the Dryad Digital Repository: http://dx.doi.org/10.5061/ dryad.5r3b1. 


\section{CONFLICT OF INTEREST}

The authors declare no conflict of interest.

\section{ACKNOWLEDGEMENTS}

This work was supported by a BBSRC postgraduate studentship and a Genetics Society Heredity fieldwork Grant to MK Sobczyk, and by the award of Pilot Project Grant NBAF711 from the NERC Biomolecular Analysis Facility (NBAFEdinburgh) to JACS. DAF acknowledges support from NERC (project NE/ G017646/1). We also thank Carlos Aguiar, Gerardo Albela González, Alfredo Asensi Marfil, Félix Llamas García, Teresa Navarro, Gonzalo Nieto Feliner, Celestino Quintela Sabarís and Julia Sánchez Vilas for assistance with locating material in the field.

Adamidis GC, Aloupi M, Kazakou E, Dimitrakopoulos PG (2014). Intra-specific variation in $\mathrm{Ni}$ tolerance, accumulation and translocation patterns in the Ni-hyperaccumulator Alyssum lesbiacum. Chemosphere 95: 496-502.

Anacker BL (2014). The nature of serpentine endemism. Am J Bot 101: 219-224.

Anacker BL, Harrison SP (2012). Climate and the evolution of serpentine endemism in California. Evol Ecol 26: 1011-1023.

Anacker BL, Whittall JB, Goldberg EE, Harrison SP (2011). Origins and consequences of serpentine endemism in the California flora. Evolution 65: 365-376.

Antonovics J, Bradshaw AD, Turner RG (1971). Heavy metal tolerance in plants. Adv Ecol Res 7: 1-85.

Baker AJM, Brooks RR (1989). Terrestrial higher plants which hyperaccumulate metallic elements. A review of their distribution, ecology and phytochemistry. Biorecovery 1: 81-126.

Baker AJM (1981). Accumulators and excluders - strategies in the response of plants to heavy-metals. J Plant Nutr 3: 643-654.

Baker AJM, McGrath SP, Reeves RD, Smith JAC (2000). Metal hyperaccumulator plants: a review of the ecology and physiology of a biological resource for phytoremediation of metal-polluted soils. In: Terry N, Bañuelos G (eds). Phytoremediation of Contaminated Soil and Water. Lewis Publishers: Boca Raton, LA, USA, pp 85-107.

Ball PW, Dudley TR (1993). Alyssum L. In: Tutin TG et al. (eds). Flora Europaea, Volume 1, Psilotaceae to Platanaceae. Second Edition. Cambridge University Press: Cambridge, pp 359-369.

Bert V, Macnair MR, de Laguérie P, Saumitou-Laprade P, Petit D (2000). Zinc tolerance and accumulation in metallicolous and nonmetallicolous populations of Arabidopsis halleri (Brassicaceae). New Phytologist 146: 225-233.

Bert V, Bonnin I, Saumitou-Laprade P, de Laguérie P, Petit D (2002). Do Arabidopsis halleri from nonmetallicolous populations accumulate zinc and cadmium more effectively than those from metallicolous populations? New Phytol 155: 47-57.

Besnard G, Basic N, Christin PA, Savova-Bianchi D, Galland N (2009). Thlaspi caerulescens (Brassicaceae) population genetics in western Switzerland: is the genetic structure affected by natural variation of soil heavy metal concentrations? New Phytol 181: 974-984.

Bonnet ALM (1963). Contribution à l'étude caryologique du genre Alyssum L. (s. lat.). Nat Monspel Sér Bot 15: 41-52.

Boyd RS (2004). Ecology of metal hyperaccumulation. New Phytol 162: 563-567.

Boyd RS (2007). The defense hypothesis of elemental hyperaccumulation: status, challenges and new directions. Plant Soil 293: 153-176.

Boyd RS, Martens S (1992). The raison d'être for metal hyperaccumulation by plants. In: Baker AJM, Proctor J, Reeves RD (eds). The Vegetation of Ultramafic (Serpentine) Soils. Intercept Ltd: Andover, UK, pp 279-289.

Brady KU, Kruckeberg AR, Bradshaw JH (2005). Evolutionary ecology of plant adaptation to serpentine soils. Annu Rev Ecol Evol Syst 36: 243-266.

Brooks RR (1987). Serpentine and Its Vegetation: A Multidisciplinary Approach. Dioscorides Press: Portland, OR, USA.

Brooks RR (1998). Plants That Hyperaccumulate Heavy Metals: Their Role in Phytoremediation, Microbiology, Archaeology, Mineral Exploration and Phytomining. CAB International: Wallingford, UK.

Brooks RR, Shaw S, Asensi Marfil A (1981). Some observations on the ecology, metal uptake and nickel tolerance of Alyssum serpyllifolium subspecies from the Iberian peninsula. Vegetatio 45: 183-188.

Burge DO, Barker WR (2010). Evolution of nickel hyperaccumulation by Stackhousia tryonii (Celastraceae), a serpentinite-endemic plant from Queensland, Australia. Aust Syst Bot 23: 415-430.

Cecchi L, Colzi I, Coppi A, Gonnelli C, Selvi F (2013). Diversity and biogeography of Ni-hyperaccumulators of Alyssum section Odontarrhena (Brassicaceae) in the central western Mediterranean: evidence from karyology, morphology and DNA sequence data. Bot J Linn Soc 3: 269-289.

Coombs JA, Letcher BH, Nislow KH (2008). create: a software to create input files from diploid genotypic data for 52 genetic software programs. Mol Ecol Resour 8: 578-580.

de la Fuente V, Rodríguez N, Díez-Garretas B, Rufo L, Asensi A, Amils R (2007). Nickel distribution in the hyperaccumulator Alyssum serpyllifolium Desf. spp. from the Iberian peninsula. Plant Biosyst 141: 170-180.
Dudley TR (1986a). A new nickelophilous species of Alyssum (Cruciferae) from Portugal, Alyssum pintodasilvae TR Dudley. Feddes Rep 97: 135-138.

Dudley TR (1986b). A nickel hyperaccumulating species of Alyssum from Spain: Alyssum malacitanum (Rivas Goday) TR Dudley, comb. \& stat. nov. Feddes Rep 97: 139-142.

Earl DA, vonHoldt BM (2012). Structure Harvester: a website and program for visualizing Structure output and implementing the Evanno method. Conserv Genet Resour 4: 359-361.

Elmendorf SC, Moore KA (2007). Plant competition varies with community composition in an edaphically complex landscape. Ecology 88: 2640-2650.

Escarré J, Lefèbure C, Gruber W, Leblanc M, Lepart J, Rivière Y et al. (2000). Zinc and cadmium hyperaccumulation by Thlaspi caerulescens from metalliferous and nonmetalliferous sites in the Mediterranean area: implications for phytoremediation. New Phytol 145: 429-437.

Evanno G, Regnaut S, Goudet J (2005). Detecting the number of clusters of individuals using the software STRUCTURE: a simulation study. Mol Ecol 14: 2611-2620.

Excoffier L, Laval G, Schneider S (2005). Arlequin (version 3.0): an integrated software package for population genetics data analysis. Evol Bioinform Online 1: 47-50.

Falush D, Stephens M, Pritchard JK (2003). Inference of population structure using multilocus genotype data: linked loci and correlated allele frequencies. Genetics 164: $1567-1587$.

Felsenstein J (2005). PHYLIP (Phylogeny Inference Package) version 3.6. Distributed by the author.

Fernandes AMFS, Queirós M (1973). Contribuiçao para o conhecimento citotaxonómico das spermatophyta de Portugal IX. Bol Soc Brot ser 2: 315-355.

Flynn TA (2013). Evolution of Nickel Hyperaccumulation in Alyssum L. D.Phil. thesis. University of Oxford.

Fones H, Davis CAR, Rico A, Fang F, Smith JAC, Preston GM (2010). Metal hyperaccumulation armors plants against disease. PloS Pathog 6: e1001093.

Freitas H, Prasad MNV, Pratas J (2004). Analysis of serpentinophytes from north-east of Portugal for trace metal accumulation - relevance to the management of mine environment. Chemosphere 54: 1625-1642.

Frérot H, Petit C, Lefèbvre C, Gruber W, Collin C, Escarré J (2003). Zinc and cadmium accumulation in controlled crosses between metallicolous and nonmetallicolous populations of Thlaspi caerulescens (Brassicaceae). New Phytol 157: 643-648.

Gao MJ, Lydiate DJ, Li X, Lui H, Gjetvaj B, Hegedus DD et al. (2009). Repression of seed maturation genes by a trihelix transcriptional repressor in Arabidopsis seedlings. Plant Cell 21: 54-71.

Gonnelli C, Galardi F, Gabbrielli R (2001). Nickel and copper tolerance and toxicity in three Tuscan populations of Silene paradoxa. Physiol Plant 113: 507-514.

Goudet J (1995). FSTAT (version 1.2): a computer program to calculate F-statistics. $J$ Hered 86: 485-486.

Halimaa P, Lin YF, Ahonen VH, Blande D, Clemens S, Gyenesei A et al. (2014). Gene expression differences between Noccaea caerulescens ecotypes help to identify candidate genes for metal phytoremediation. Environ Sci Technol 48: 3344-3353.

Hanikenne M, Nouet C (2011). Metal hyperaccumulation and hypertolerance: a model for plant evolutionary genomics. Curr Opin Plant Biol 14: 252-259.

Haydon MJ, Cobbett CS (2007). Transporters of ligands for essential metal ions in plants. New Phytolt 174: 499-506.

Hewitt GM (1999). Post-glacial re-colonization of European biota. Biol J Linn Soc 6: $87-112$.

Jakobsson M, Rosenberg NA (2007). CLUMPP: a cluster matching and permutation program for dealing with label switching and multimodality in analysis of population structure. Bioinformatics 23: 1801-1806.

Jiménez-Ambriz G, Petit C, Bourrié I, Dubois S, Olivieri I, Ronce O (2007). Life history variation in the heavy metal tolerant plant Thlaspi caerulescens growing in a network of contaminated and noncontaminated sites in southern France: role of gene flow, selection and phenotypic plasticity. New Phytol 173: 199-215.

Kazakou E, Dimitrakopoulos PG, Baker AJM, Reeves RD, Troumbis AY (2008). Hypotheses, mechanisms and trade-offs of tolerance and adaptation to serpentine soils: from species to ecosystem level. Biol Rev Camb Philos Soc 83: 495-508.

Kirchner S (2009). The AtIREGs - characterization of a new family of metal transporters in Arabidopsis thaliana. PhD thesis University of Hohenheim.

Kofler R, Schlötterer C, Lelley T (2007). SciRoKo: a new tool for whole genome microsatellite search and investigation. Bioinformatics 23: 1683-1685.

Koláŕ F, Fér T, Štech M, Trávníčk P, Dušková E, Schönswetter $P$ et al. (2012). Bringing together evolution on serpentine and polyploidy: spatiotemporal history of the diploidtetraploid complex of Knautia anvensis (Dipsacaceae). PLoS One 7: e39988.

Krämer U (2010). Metal hyperaccumulation in plants. Annu Rev Plant Biol 61: 517-534.

Kruckeberg AR (1954). The ecology of serpentine soils. 3. Plant species in relation to serpentine soils. Ecology 35: 267-274.

Kruckeberg AR (2004). Geology and Plant Life: The Effects of Landforms and Rock Types on Plants. University of Washington Press: Seattle, WA, USA.

Küpfer $\mathrm{P}$ (1974). Recherches sur les liens de parenté entre la flore orophile des Alpes et celledes Pyrénées. Boissiera 23: 3-322.

Lanquar V, Lelièvre F, Bolte S, Hames C, Alcon C, Neumann D et al. (2005). Mobilization of vacuolar iron by AtNRAMP3 and AtNRAMP4 is essential for seed germination on low iron. EMBO J 24: 4041-4051.

Lanquar V, Ramos MS, Lelièvre $\mathrm{F}$, Barbier-Brygoo $\mathrm{H}$, Krieger-Liszkay $\mathrm{A}$, Krämer $\mathrm{U}$ et al. (2010). Export of vacuolar manganese by AtNRAMP3 and AtNRAMP4 is required for optimal photosynthesis and growth under manganese deficiency. Plant Physiol 152: 1986-1999.

Levin HL (2013). The Earth through Time, 10th edn. John Wiley \& Sons: Hoboken, NJ. 
Librado P, Rozas J (2009). DnaSP v5: a software for comprehensive analysis of DNA polymorphism data. Bioinformatics 25: 1451-1452.

Macnair MR (2003). The hyperaccumulation of metals by plants. Adv Bot Res 40: 63-105.

Mantel N (1967). The detection of disease clustering and a generalized regression approach. Cancer Res 27: 209-220.

Marschner H, Marschner P (2012). Marschner's Mineral Nutrition of Higher Plants, 3rd edn. Elsevier/Academic Press: London; Waltham, MA

Mayer MS, Soltis PS, Soltis DE (1994). The evolution of the Streptanthus glandulosus complex (Cruciferae): genetic divergence and gene flow in serpentine endemics. Am J Bot 81: 1288-1299.

Meerts P, Van Isacker N (1997). Heavy metal tolerance and accumulation in metallicolous and non-metallicolous populations of Thlaspi caerulescens from continental Europe. Plant Ecol 133: 221-231.

Mengoni A, Baker AJM, Bazzicalupo M, Reeves RD, Adigüzel N, Chianni E et al. (2003). Evolutionary dynamics of nickel hyperaccumulation in Alyssum revealed by ITS nrDNA analysis. New Phytol 159: 691-699.

Merlot S, Hannibal L, Martins S, Martinelli L, Amir H, Lebrun M et al. (2014). The metal transporter PgIREG1 from the hyperaccumulator Psychotria gabriellae is a candidate gene for nickel tolerance and accumulation. J Exp Bot 65: 1551-1564.

Meyer CL, Kostecka AA, Saumitou-Laprade P, Creach A, Castric V, Pauwels M et al. (2010). Variability of zinc tolerance among and within populations of the pseudometallophyte species Arabidopsis halleri and possible role of directional selection. New Phytol 185: 130-142.

Meyer CL, Vitalis R, Saumitou-Laprade P, Castric V (2009). Genomic pattern of adaptive divergence in Arabidopsis halleri, a model species for tolerance to heavy metal. $\mathrm{Mol}$ Ecol 18: 2050-2062.

Mizuno T, Usui K, Horie K, Nosaka S, Mizuno N, Obata H (2005). Cloning of three ZIP Nramp transporter genes from a Ni hyperaccumulator plant Thlaspi japonicum and their $\mathrm{Ni}^{2+}$-transport abilities. Plant Physiol Biochem 43: 793-801.

Moore AJ, Merges D, Kadereit JW (2013). The origin of the serpentine endemic Minuartia laricifolia subsp. ophiolitica by vicariance and competitive exclusion. Mol Ecol 22 2218-2231.

Nei M (1987). Molecular Evolutionary Genetics. Columbia University Press: New York.

Nei M, Tajima F, Tateno Y (1983). Accuracy of estimated phylogenetic trees from molecular data. II. Gene frequency data. J Mol Evol 19: 153-170.

Ni X, Huang Y, Wu L, Zhou R, Deng S, Wu D et al. (2006). Genetic diversity of the endangered Chinese endemic herb Primulina tabacum (Gesneriaceae) revealed by amplified fragment length polymorphism (AFLP). Genetica 127: 177-183.

Noret N, Meerts P, Vanhaelen M, Dos Santos A, Escarré J (2007). Do metal-rich plants deter herbivores? A field test of the defence hypothesis. Oecologia 152: 92-100.

Oomen RJFJ, Wu J, Lelièvre F, Blanchet S, Richaud P, Barbier-Brygoo H et al. (2009). Functional characterization of NRAMP3 and NRAMP4 from the metal hyperaccumulator Thlaspi caerulescens. New Phytol 181: 637-650.

Pandey N, Sharma CP (2002). Effect of heavy metals $\mathrm{Co}^{2+}, \mathrm{Ni}^{2+}$ and $\mathrm{Cd}^{2+}$ on growth and metabolism of cabbage. Plant Sci 163: 753-758.

Pandolfini T, Gabbrielli R, Comparini C (1992). Nickel toxicity and peroxidase activity in seedlings of Triticum aestivum L. Plant Cell Environ 15: 719-725.

Pauwels M, Frérot H, Bonnin I, Saumitou-Laprade P (2006). A broad-scale analysis of population differentiation for $\mathrm{Zn}$ tolerance in an emerging model species for tolerance study: Arabidopsis halleri (Brassicaceae). J Evol Biol 19: 1838-1850.

Pauwels M, Saumitou-Laprade P, Holl AC, Petit D, Bonnin I (2005). Multiple origin of metallicolous populations of the pseudometallophyte Arabidopsis halleri (Brassicaceae) in central Europe: the cpDNA testimony. Mol Ecol 14: 4403-4414.

Pollard AJ, Powell KD, Harper FA, Smith JAC (2002). The genetic basis of metal hyperaccumulation in plants. Crit Rev Plant Sci 21: 539-566.

Pollard AJ, Reeves RD, Baker AJM (2014). Facultative hyperaccumulation of heavy metals and metalloids. Plant Sci 21: 8-17.

Porebski S, Bailey LG, Baum BR (1997). Modification of a CTAB DNA extraction protocol for plants containing high polysaccharide and polyphenol components. Plant $\mathrm{Mol} B i o l$ Reporter 15: 8-15.

Poschenrieder C, Tolrà R, Barceló J (2006). Can metals defend plants against biotic stress? Trends Plant Sci 11: 288-295.

Pottier M, Oomen R, Picco C, Giraudat J, Scholz-Starke J, Richaud P et al. (2015) Identification of mutations allowing Natural Resistance Associated Macrophage Proteins (NRAMP) to discriminate against cadmium. Plant J 83: 625-637.

Pritchard JK, Stephens M, Donnelly P (2000). Inference of population structure using multilocus genotype data. Genetics 155: 945-959.

Proctor J (1975). The ecology of serpentine soils. Adv Ecol Res 9: 255-366.

Puech S (1963). Introduction à une monographie d'Anduze (Gard): étude écologique et caryosystématique de quelques taxa cévenols. Nat Monspel Sér Bot 15: 125-129.

Qadir S, Qureshi M, Javed S, Abdin M (2004) Genotypic variation in phytoremediation potential of Brassica juncea cultivars exposed to Cd stress. Plant Science 167 1171-1181.

Quintela-Sabarís C, Vendramin GG, Castro-Fernández D, Fraga MI (2010). Chloroplast microsatellites reveal that metallicolous populations of the Mediterranean shrub Cistus ladanifer L. have multiple origins. Plant Soil 334: 161-174.

Rahman H, Sabreen S, Alam S, Kawai S (2005). Effects of nickel on growth and composition of metal micronutrients in barley plants grown in nutrient solution. J Plant Nutr 28: 393-404.
Ralser M, Querfurth R, Warnatz HJ, Lehrach H, Yaspo ML, Krobitsch S (2006). An efficient and economic enhancer mix for PCR. Biochem Biophys Res Commun 347: 747-751.

Rascio N, Navari-Izzo F (2011). Heavy metal hyperaccumulating plants: how and why do they do it? And what makes them so interesting? Plant Sci 180: 169-181.

Raymond M, Rousset F (1995). GENEPOP (version 1.2): population genetics software for exact tests and ecumenicism. J Hered 86: 248-249.

Reeves R (1992). The hyperaccumulation of nickel by serpentine plants. In: Baker AJM, Proctor J, Reeves RD (eds). The Vegetation of Ultramafic (Serpentine) Soils. Intercept Ltd.: Andover, UK, pp 253-277.

Reeves RD, Baker AJM (2000). Phytoremediation of Toxic Metals: Using Plants to Clean up the Environment. Wiley: New York, USA.

Rešetnik I, Satovic Z, Schneeweiss GM, Liber Z (2013). Phylogenetic relationships in Brassicaceae tribe Alysseae inferred from nuclear ribosomal and chloroplast DNA sequence data. Mol Phylogenet Evol 69: 772-786.

Rogers SO, Bendich AJ (1985). Extraction of DNA from milligram amounts of fresh, herbarium and mummified plant tissues. Plant Mol Biol 5: 69-76.

Roosens N, Verbruggen N, Meerts P, Ximénez-Embún P, Smith JAC (2003). Natural variation in cadmium tolerance and its relationship to metal hyperaccumulation for seven populations of Thlaspi caerulescens from western Europe. Plant Cell Environ 26: 1657-1672.

Ros R, Morales A, Segura J, Picazo I (1992) In vivo and in vitro effects of nickel and cadmium on the plasmalemma ATPase from rice (Oryza sativa L.) shoots and roots. Plant Science 83: 1-6.

Rosenberg NA (2004). DISTRUCT: a program for the graphical display of population structure. Mol Ecol Notes 137-138.

Roux C, Castric V, Pauwels M, Wright SI, Saumitou-Laprade P, Vekemans X (2011). Does speciation between Arabidopsis halleri and Arabidopsis lyrata coincide with major changes in a molecular target of adaptation? PloS One 6: e26872.

Rundle HD, Nosil P (2005). Ecological speciation. Ecol Lett 8: 336-352.

Salmerón-Sánchez E, Martínez-Nieto M, Martínez-Hernández F, Garrido-Becerra J, Mendoza-Fernández A, de Carrasco C et al. (2014a). Ecology, genetic diversity and phylogeography of the Iberian endemic plant Jurinea pinnata (Lag.) DC. (Compositae) on two special edaphic substrates: dolomite and gypsum. Plant Soil 374 233-250.

Salmerón-Sánchez E, Merlo ME, Medina-Cazorla JM, Pérez-García FJ, Martínez-Hernández F, Garrido-Becerra JA et al. (2014b). Variability, genetic structure and phylogeography of the dolomitophilous species Convolvulus boissieri (Convolvulaceae) in the Baetic ranges, inferred from AFLPs, plastid DNA and ITS sequences. Bot J Linn Soc 176: 506-523.

Schat H, Vooijs R, Kuiper E (1996). Identical major gene loci for heavy metal tolerances that have independently evolved in different local populations and subspecies of Silene vulgaris. Evolution 50: 1888-1895.

Španiel S, Kempa M, Salmerón-Sánchez E, Fuertes-Aguilar J, Mota JF, AI-Shehbaz IA et al. (2015). AlyBase: database of names, chromosome numbers, and ploidy levels of Alysseae (Brassicaceae), with a new generic concept of the tribe. Plant Syst Evol 301 2463-2491.

Stebbins GL (1942). The genetic approach to problems of rare and endemic species. Madroño 60: 302-319.

Stebbins GL, Major J (1965). Endemism and speciation in the California flora. Ecol Monogr 35: 1-35.

Stephens M, Smith NJ, Donnelly P (2001). A new statistical method for haplotype reconstruction from population data. Am J Hum Genet 68: 978-989.

Takezaki N, Nei M, Tamura K (2010). POPTREE2: Software for constructing population trees from allele frequency data and computing other population statistics with Windows interface. Mol Biol Evol 27: 747-752.

Tamura K, Stecher G, Peterson D, Filipski A, Kumar S (2013). MEGA6: Molecular Evolutionary Genetics Analysis version 6.0. Mol Biol Evol 30: 2725-2729.

Thomine S, Lelievre F, Debarbieux E, Schroeder JI, Barbier-Brygoo H (2003). AtNRAMP3, a multispecific vacuolar metal transporter involved in plant responses to iron deficiency. Plant J 34: 685-695.

Thomine S, Wang R, Ward JM, Crawford NM, Schroeder JI (2000). Cadmium and iron transport by members of a plant metal transporter family in Arabidopsis with homology to Nramp genes. Proc Natl Acad Sci USA 97: 4991-4996.

Turner TL, Bourne EC, Von Wettberg EJ, Hu TT, Nuzhdin SV (2010). Population resequencing reveals local adaptation of Arabidopsis lyrata to serpentine soils. Nat Genet 42: 260-263.

Van der Ent A, Baker AJM, Reeves RD, Pollard AJ, Schat H (2013). Hyperaccumulators of metal and metalloid trace elements: facts and fiction. Plant Soil 362: 319-334.

Van Oosterhout C, Hutchinson WF, Wills DP, Shipley P (2004). MICRO-CHECKER: software for identifying and correcting genotyping errors in microsatellite data. Mol Ecol Notes 4: 535-538.

Vekemans X, Lefèbvre C (1997). On the evolution of heavy-metal tolerant populations in Armeria maritima: evidence from allozyme variation and reproductive barriers. J Evol Biol 10: 175-191.

Verbruggen N, Hermans C, Schat H (2009). Molecular mechanisms of metal hyperaccumulation in plants. New Phytol 181: 759-776.

Weir BS, Cockerham CC (1984). Estimating F-statistics for the analysis of population structure. Evolution 38: 1358-1370.

Wright S (1943). Isolation by distance. Genetics 28: 114-138.

Yoon H, Leitner T (2015). PrimerDesign-M: a multiple-alignment based multiple-primer design tool for walking across variable genomes. Bioinformatics 31: 1472-1474. 